\title{
Development Performance across Indian States and The Role of the Governments
}

\author{
Kaliappa Kalirajan* \\ Crawford School of Economics and Government, Australian National University, \\ Foundation for Advanced Studies on International Development and \\ National Graduate Institute for Policy Studies, Tokyo
}

\section{Shashanka Bhide}

National Council of Applied Economic Research, New Delhi

and

Kanhaiya Singh

National Council of Applied Economic Research, New Delhi

\begin{abstract}
India has a federal system of governance with both the state or provincial and the Central governments responsible for the development of the nation as a whole. Policies at the Central as well as state levels influence the state level variations in economic conditions in turn. It is in this context, this paper examines whether governments in India within a federal framework have been able to foster development equitably across its states.

Overall, the results in this paper indicate that Government in India within a federal framework has mechanisms that foster development equitably across its states, particularly through health and education expenditures aimed at improving human capital development. However, the slowly rising disparities in economic services across states warrant the Central and state governments' attention.
\end{abstract}

JEL Classification: E62 and H70

Keywords: Government, interstate transfer, development expenditure, India.

\footnotetext{
${ }^{*}$ The authors are grateful to Keijiro Otsuka for his valuable comments and suggestions, which materially improved this paper
} 


\section{Background}

Since the early 1980s, publications in economic geography, regional economics, and development economics have demonstrated the significance of small geographical regions within a national boundary as nexus of critical developmental and growth processes. Theorists and empirical economists who have made substantial contributions in this area of research recently are, among others, Hayami (1998), Fujita, Krugman, and Venables (1999), Krugman (2000), Schmitz (2000), Porter (2001), Sonobe, Hu, and Otsuka (2002), Sonobe and Otsuka (2006), and World Bank (2009). Except Hayami, who advocates geographical dispersion of industries, others implicitly support geographically concentrated industrialization. These latter studies have repeatedly suggested that such industrial clusters are capable of facilitating significant growth-transmission effects to national growth with a positive impact on the convergence of living standards across regions. However, as argued by Parente and Prescott (2000) not 'everything else' would remain the same for the growthtransmission effects to take place effectively and therefore, the reduction in regional development disparity, if any, has not been conspicuous. Further, there are empirical studies in the literature, which have raised doubts about the existence of spillover or trickling down effects from advanced regions to disadvantaged regions (Gaile, 1980; Higgins, 1983). Hence in reality, achieving equitable development across regions has been a serious concern in many developing countries.

In the context of balanced regional development, drawing on the East Asian model of industrial development recently discussed in Sonobe and Otsuka (2006), a relevant point that needs to be made at the outset is that less equitable spatial development is not necessarily an indicator of constraints to overall growth of the economy. Yet, if large and populous spatial segments of the economy remained backward while the other regions move ahead for long periods of time, the overall national development strategy become unsustainable (World Bank, 2009). The crucial questions in this context are about how to bring spatially equitable development in a country and which institution has the primary responsibility for bringing such equitable development. Conventionally, an economic system is comprised of state and market, which means the primary responsibility for spatially equitable development rests with either or both state and market. While a federal framework provides for allocation of state resources in an equitable manner, the market operates based on business perspectives that may not aim for spatially equitable development. In contrast to the conventional method of assigning the factors contributing to socio-economic development either to state or to market, Hayami (2004) introduced another relevant entity 'community'. Communities are expected to maintain benefits for their members in a sustainable manner at the local level, a strategy that may again not have spatial equity as an objective. The task of achieving balanced development has, therefore, been primarily assigned to 'state' and neither to 'market' nor to ‘community'. Even Hirschman (1958), who was a proponent of focused or 
'unbalanced' industrialization, earlier strongly argued for governmental intervention to counteract the 'polarization effects' of free market forces in order to mitigate the misfortune of the 'backward regions'.

India has a federal system of governance with both the state or provincial and the Central governments responsible for the development of the nation as a whole. Policies at the Central as well as state level influence the state level variations in economic conditions in turn. It is in this context, this paper examines whether governments in India within a federal framework have been able to foster development equitably across its states. ${ }^{1}$

The following section describes the approach followed in this paper to examine the existence of equitable development across states in India. Spatial diversity of the Indian economy concerning its overall growth is shown in the next section, which is followed by a discussion on the existing spatial diversity in basic development indicators. The next section attempts to explain the probable causes for variations in development across states in India. Empirical identification of factors influencing variations in development across states is presented in the following section. A final section brings out the overall conclusions of this paper.

\section{The Approach}

A sizable literature has now become available on patterns and determinants of economic growth at the national level in India. However, research on patterns and determinants of important development indicators at sub-national level is relatively small in number. ${ }^{2}$ To have a bird's eye view of development of a country, per capita gross domestic product (GDP) is generally used as a measure. It is understood that GDP alone neither says anything about distribution of income, nor about how it is used. If development is about people and how they live, then one needs a measure of the level of living of the population, into which is built a distributive element of income. In this context, it is worth citing the statements from the Indian Prime Minister's Forward to Planning Commission's Eleventh Five Year Plan, “The transition to high growth is an impressive achievement, but we must not forget that growth is not the only measure of development. Our ultimate objective is to achieve broad based improvement in the living standards of all our people” (Planning Commission, 2008, p. iii).

Drawing on the United Nations Research Institute for Social Development (UNRISD, 1968), and based on the uniform availability of data, the following variables that represent a

\footnotetext{
${ }^{1}$ Though state has to take a leading role towards achieving balanced regional development, as Hayami (2001) has argued, the final outcome with respect to development, including equitable regional development is a result of the interaction between the state, market, and community.

${ }^{2}$ For a recent analysis at the national level, see Jha (2008): for a recent state level discussion on economic reforms in India, see Howes, Lahiri and Stern (2003)
} 
wide range of basic developmental aspects of an economy, all of which tend to change more or less simultaneously as the society develops, are considered in this study: Infant mortality rate (IMR), Life expectancy at birth (LE), Literacy rate (LR), Telecom density per thousand population (TD), and per capita Electricity consumption (EC) in kwh. ${ }^{3}$ Admittedly, these indicators refer to the very basic needs of life and it is expected that the state and Central governments at different levels would strive to bridge the spatial gap in these dimensions of development within India. Thus, first, spatial distribution of these above variables along with gross state domestic product (GSDP) is determined over the years to gauge the effectiveness of region specific constraints or accelerators of development. The next step in the analysis is an attempt to explain the causes for variations in actual status of those developmental variables across states. Finally, the role of the state and Central governments in fostering equitable development across regions is examined.

\section{Spatial Diversity in Overall Growth of the Indian Economy}

The record of India's economic growth rate in the period from 1980-81 to 2006-07 has been sharply higher than in the previous three decades since her independence in 1947. This growth acceleration has been projected to continue over the medium term by a number of observers (For example Kelkar, 2004, and Rodrik and Subramanian, 2004). At the aggregate level, the rise in investment spending relative to overall GDP has been a proximate cause of higher output growth. There has been higher investment in physical and social infrastructure over the years leading to better performance in terms of both physical output and also in human capital development indicators. While improvements have been conspicuous in terms of India's own performance in the past and not with respect to a global comparative scale, the improvements have led to expectations that India will be able to deliver higher average levels of living to her rising population. However, the conventional wisdom implies that disparities may also grow along with economic growth at least in the early periods of the growth process.

India's past record, even before the launching of the economic reforms in the early 1990s, also points to wide variations across its sub-national units, states. ${ }^{4}$ The federal framework is expected to achieve a more balanced development of the diverse country than a centralised rule, as the decentralised governance can be expected to utlilise the available resources more efficiently to meet the aspirations of the local population (Hayami, 2001).

\footnotetext{
${ }^{3}$ Infant mortality rate, life expectancy at birth, and literacy rate can be considered as basic indicators of human capital development. Telephone density and per capita electricity consumption can be considered as indicators of infrastructural development of the economy.

${ }^{4}$ India is a Federation of States with responsibilities divided between the States and the Centre for development efforts. The third tier of government, the local governments, is now gradually emerging as significant independent entities.
} 
At a general level, the extent of variation in the Indian economy can be illustrated by the broad measures of the size of the state economies. There are 29 states in India with their own democratically elected assemblies. Among these, 10 states have population of more than 50 million. There are eight states with population below 5 million. Six states have a gross state domestic product (GSDP) of more than $\$ 50$ billion. Table 1 provides the profile of the states in terms of size of the population and economies.

In a bird's eye view of the level of economic development, it is apparent from the fact that only five states have a per capita GSDP of more than $\$ 900$ and only two have a per capita GSDP of more than $\$ 1000$, though these two are relatively smaller states in terms of population and economic activities. Among the states with a population of more than 50 million, Bihar and Uttar Pradesh have the lowest per capita GSDP of below $\$ 350$ and Maharashtra and Gujarat, which are the industrially advanced states, have the per capita GSDP of more than $\$ 900$.

Some insights into the trends concerning divergence in economic growth across states can be obtained through the coefficient of variation in per capita income across the states over time. Following Kalirajan and Akita (2004), the weighted coefficient of variation of per capita gross state domestic product (GSDP) in constant 1993-94 prices for the period 198081 to 2004-05 is calculated. ${ }^{5}$

The trends shown in Figure 1 indicate that there has been an increase in disparity concerning per capita gross state domestic product as captured by this measure. The increase appears to be relatively sharper in the years of 1990-91, in which economic reforms were instituted, and later. The decade before this period has been one of relative stability in spatial disparity. Bhattacharya and Sakthivel (2004) have presented an analysis that shows rising level of inter-state disparity in per capita state domestic product, which corroborates our results for the post-reform periods.

What are the factors that reduce such disparity in development and which factors do enhance it?

\section{Explaining the growth differential across states}

Following the seminal work of Barro (1991), the basic methodology of growth studies consists of running a cross-section regression of the following form

$$
\Delta y p c=c+\sum_{i=1}^{n} \beta_{i} x_{i}+\varepsilon
$$

\footnotetext{
${ }^{5}$ The weighted coefficient of variation is calculated as follows: $\quad c v=\frac{1}{Y^{*}}{\sqrt{\sum_{i}^{n}\left(Y_{i}-Y^{*}\right)}}^{2} \frac{P_{i}}{P}$ where $\mathrm{P}_{\mathrm{i}}$ refers to population of the ith state; $\mathrm{P}$ refers to population of the country; $\mathrm{Y}_{\mathrm{i}}$ refers to per capita GSDP; $\mathrm{Y}^{*}$ refers to per capita national income; and n refers to number of states.
} 
where $c$ is a constant, $x_{i}$ represents a vector of $i^{\text {th }}$ explanatory variable in the regression. $\triangle y p c$ represents a vector of per capita growth rates, and $\varepsilon$ is a statistical error term. A typical assumption of such studies is that other conditions than those incorporated in the model are similar. Although across countries it is considered to be a strong assumption, in the case of states within a particular country such assumption may not be so strong. Thus, it is assumed that all states have uniformity in terms of behavior, access to advanced technology, global environment and have equal opportunities with a central planner who takes care of the local disadvantages and advantages and the resources are freely and optimally utilized by the elected representatives of a particular state.

Figure 1 Trends in spatial disparity in per capita GSDP: weighted coefficient of variation across states

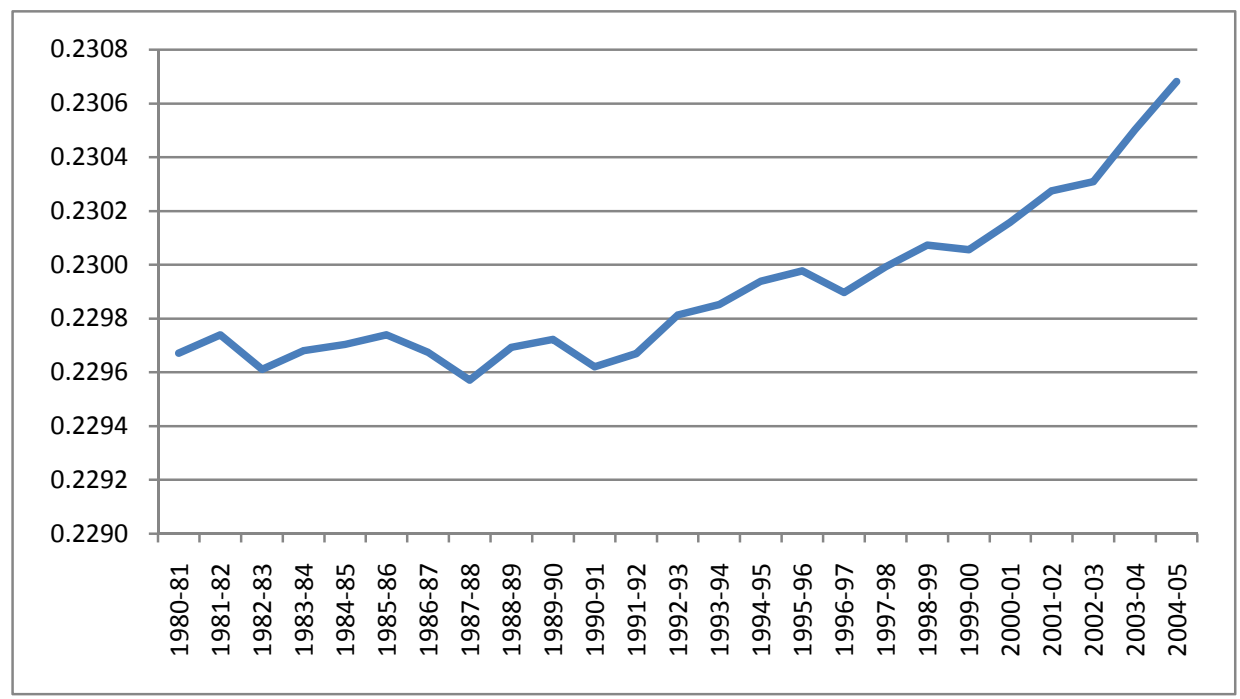

Note: Coefficient of variation in per capita GSDP (1993-94 prices) was calculated using data for 16 major states using state population as weights.

One of the key requirements of running the above regression is to apriorily identify variables that have theoretical basis for causing variations in growth because then only it can be established that variations in such variables across states would have resulted in significantly different rates of economic growth across states. In the case of cross-country regressions a number of such variables have been identified, but in the case of states of a single country choices are rather limited. The idea here is not simply to test the hypothesis of convergence or divergence, but also to identify variables that explain differences in growth across the Indian States. At the outset, based on theory and also on the availability of uniform data across states, the following reduced form equation was estimated to examine the conditional convergence of per capita real gross domestic product across states after controlling for some of the important human capital and physical capital indicators:

$$
S Y P C 1=\alpha_{1}+\alpha_{2} S Y P C 8081+\alpha_{3} L I T 8081+\alpha_{4} S T P O P+\alpha_{5} I N V+\alpha_{6} C s t+u_{1}
$$


With the expected results of either convergence or divergence, the next interesting question concerns identification of important variables explaining differences in growth of per capita real gross domestic product, for which the following equation was estimated:

$S Y P C 2=\beta_{1}+\beta_{2} A G R 8081+\beta_{3} M F G 8081+\beta_{4} L I T 8081+\beta_{5} S T P O P+\beta_{6} I N V+\beta_{7} C s t+u_{2}(2)$

Table 1 Size and income of India's States and Union territories (2005-06)

\begin{tabular}{|c|c|c|c|c|c|c|}
\hline \multirow{2}{*}{ Sl. No. } & \multirow{2}{*}{ State/ UT } & \multirow{2}{*}{$\begin{array}{c}\text { Population } \\
\text { Million }\end{array}$} & \multicolumn{2}{|c|}{ GSDP } & \multicolumn{2}{|c|}{ Per capita GSDP } \\
\hline & & & Rs Billion & Billion US\$ & Rs & US\$ \\
\hline 1 & Andhra & 80.4 & 2360 & 53.32 & 29369 & 663 \\
\hline 2 & Arunachal Pradesh & 1.2 & 29 & 0.66 & 25086 & 567 \\
\hline 3 & Assam & 28.5 & 575 & 13.00 & 20186 & 456 \\
\hline 4 & Bihar & 90.2 & 802 & 18.11 & 8891 & 201 \\
\hline 5 & Jharkhand & 29.1 & 622 & 14.06 & 21377 & 483 \\
\hline 6 & Goa & 1.6 & 124 & 2.80 & 79389 & 1793 \\
\hline 7 & Gujarat & 54.6 & 2198 & 49.65 & 40221 & 909 \\
\hline 8 & Haryana & 23.1 & 1064 & 24.03 & 45974 & 1038 \\
\hline 9 & Himachal & 6.6 & 255 & 5.75 & 38457 & 869 \\
\hline 10 & Jammu \& Kashmir & 10.9 & 265 & 5.99 & 24397 & 551 \\
\hline 11 & Karnataka & 56.0 & 1680 & 37.94 & 29999 & 678 \\
\hline 12 & Kerala & 33.4 & 1190 & 26.88 & 35601 & 804 \\
\hline 13 & Madhya Pradesh & 65.9 & 1163 & 26.28 & 17649 & 399 \\
\hline 14 & Chattisgarh & 22.7 & 519 & 11.73 & 22873 & 517 \\
\hline 15 & Maharashtra & 104.2 & 4381 & 98.95 & 42056 & 950 \\
\hline 16 & Manipur & 2.5 & 57 & 1.29 & 22684 & 512 \\
\hline 17 & Meghalaya & 2.5 & 63 & 1.43 & 25699 & 581 \\
\hline 18 & Mizoram & 1.0 & 27 & 0.61 & 27027 & 610 \\
\hline 19 & Nagaland & 2.5 & 57 & 1.28 & 22736 & 514 \\
\hline 20 & Orissa & 38.8 & 785 & 17.74 & 20251 & 457 \\
\hline 21 & Punjab & 26.5 & 1097 & 24.79 & 41420 & 936 \\
\hline 22 & Rajasthan & 61.8 & 1242 & 28.06 & 20095 & 454 \\
\hline 23 & Sikkim & 0.6 & 18 & 0.41 & 31186 & 704 \\
\hline 24 & Tamil Nadu & 64.9 & 2235 & 50.49 & 34424 & 778 \\
\hline 25 & Tripura & 3.4 & 94 & 2.12 & 27694 & 626 \\
\hline 26 & Uttar Pradesh & 181.9 & 2798 & 63.19 & 15382 & 347 \\
\hline 27 & Uttaranchal & 9.2 & 262 & 5.91 & 28572 & 645 \\
\hline 28 & West Bengal & 84.8 & 2347 & 53.02 & 27668 & 625 \\
\hline \multirow[t]{2}{*}{29} & Pondicherry & 2.6 & 68 & 1.45 & 25712 & 588 \\
\hline & All India & 1116.1 & 32757 & 739.93 & 29350 & 663 \\
\hline
\end{tabular}


An interesting issue to be explored in this context is whether productive agricultural sector is a prerequisite for the growth of manufacturing sector or comparative disadvantage in agriculture stimulates the growth of manufacturing sector for survival. The potential variables to testing the above hypothesis include initial conditions of agricultural growth and manufacturing growth, literacy rate, demographic composition, investment, and the existence of coastal region.

$$
\begin{aligned}
& A G R I \_G S D P=\gamma_{1}+\gamma_{2} A G R 8081+\gamma_{3} M F G 8081+\gamma_{4} L I T 8081+\gamma_{5} S T P O P+\gamma_{6} I N V+\gamma_{7} C s t+u_{3} \\
& M F G \_G S D P=\delta_{1}+\delta_{2} A G R 8081+\delta_{3} M F G 8081+\delta_{4} L I T 8081+\delta_{5} S T P O P+\delta_{6} I N V+\delta_{7} C s t+u_{4}
\end{aligned}
$$

The symbols in the estimated equations are as follows:

SYPC = per capita growth of real gross state domestic product, YPC8081 = per capita gross state domestic product in 1980-81; AGRI_GSDP = per capita growth in agricultural real gross state domestic product; MFG_GSDP = per capita growth in manufacturing real gross state domestic product; AGR8081 = initial agricultural condition, which is 1980-81 share of agriculture sector in GSDP; MFG8081 = initial manufacturing condition, which is 1980-81 share of manufacturing sector in GSDP (all taken in fractions); LIT8081 = literacy rate in 1980-81 as an initial condition variable; INV = real investment as fraction of real GSDP; Cst = dummy variable taking the value of 1 for the presence of coastal area and zero otherwise; STPOP = Schedule Tribe fraction of population; and ST components are from the census 1991 data.

Each of the above four growth equations was estimated using the data for 29 Indian states for the post-reform period of 1993-94 to 1999-2000 following general to specific approach and the results are presented in Table 2. Relevant variables are presented at 1993-94 constant prices. The model captures some of the features of social and economic diversity across states. The results presented below discuss only those variables that are found to be important in terms of statistical significance for the Indian States.

The R- bar squares for all equations are significantly large and the residuals are well within the band of two standard errors and therefore, the models capture most of the variations in per capita growth in real total value addition, agriculture value addition and in manufacturing value addition across states and can lead to valid conclusions. ${ }^{6}$ The important results are that there is divergence with respect to per capita growth in real gross state domestic product across states and that unlike in the East Asian model of economic growth, having productive agricultural sector as initial condition for the growth of manufacturing sector is not valid in the Indian context. The inference is that having comparative disadvantage in agriculture stimulates the growth of manufacturing sector for survival. ${ }^{7}$

\footnotetext{
${ }^{6}$ The above results have been corroborated by an alternative estimation of generalized method of moments.

${ }^{7}$ The authors are grateful to Keijiro Otsuka for discussion on this point.
} 
Table 2 Explaining the variations in real per capita growth in the post-reform periods

\begin{tabular}{|c|c|c|c|c|}
\hline Variables & SYPC 1 & SYPC 2 & AGRI_GSDP & MFG_GSDP \\
\hline Constant & $\begin{array}{l}-0.253^{\star} \\
(0.124)\end{array}$ & $\begin{array}{l}-0.142^{\star} \\
(0.051)\end{array}$ & $\begin{array}{c}0.059^{* *} \\
(0.025)\end{array}$ & $\begin{array}{c}0.273^{\star \star} \\
(0.128)\end{array}$ \\
\hline YPC8081 & $\begin{array}{c}0.248^{\star *} \\
(0.110)\end{array}$ & & & \\
\hline AGR8081 & & $\begin{array}{c}0.133^{\star \star} \\
(0.063)\end{array}$ & $\begin{array}{c}0.152^{*} \\
(0.034)\end{array}$ & $\begin{array}{l}-0.106^{\star} \\
(0.024)\end{array}$ \\
\hline MFG8081 & & $\begin{array}{c}0.252^{\star \star} \\
(0.121)\end{array}$ & $\begin{array}{l}-0.157^{\star \star} \\
(0.069)\end{array}$ & $\begin{array}{c}0.756^{\star \star} \\
(0.356)\end{array}$ \\
\hline LIT8081 & $\begin{array}{c}0.137^{\star *} \\
(0.058)\end{array}$ & $\begin{array}{c}0.108^{\star \star} \\
(0.052)\end{array}$ & $\begin{array}{l}-0.470 \\
(0.338)\end{array}$ & $\begin{array}{c}0.867^{\star *} \\
(0.414)\end{array}$ \\
\hline STPOP & $\begin{array}{c}0.032^{\star \star} \\
(0.015) \\
\end{array}$ & $\begin{array}{c}0.024^{\star *} \\
(0.011)\end{array}$ & $\begin{array}{c}0.027^{\star \star} \\
(0.012)\end{array}$ & $\begin{array}{l}-0.02 \\
(0.032)\end{array}$ \\
\hline INV & $\begin{array}{c}0.054^{\star *} \\
(0.026)\end{array}$ & $\begin{array}{c}0.063^{\star \star} \\
(0.028)\end{array}$ & $\begin{array}{c}0.038^{\star *} \\
(0.016)\end{array}$ & $\begin{array}{c}0.056^{\star *} \\
(0.027)\end{array}$ \\
\hline Cst & $\begin{array}{c}0.050^{*} \\
(0.023) \\
\end{array}$ & $\begin{array}{c}0.047^{\star *} \\
(0.022) \\
\end{array}$ & $\begin{array}{l}-0.011^{\star \star} \\
(0.005)\end{array}$ & $\begin{array}{c}0.052^{\star \star} \\
(0.025)\end{array}$ \\
\hline $\begin{array}{l}\text { R-bar square } \\
\text { Functional form } \mathrm{CHSQ}(1) \\
\text { Heteroscedasticity } \mathrm{CHQ}(1)\end{array}$ & $\begin{array}{l}0.88 \\
0.42[0.54] \\
0.18[0.23]\end{array}$ & $\begin{array}{l}0.82 \\
0.36[0.54] \\
0.16[0.23]\end{array}$ & $\begin{array}{l}0.72 \\
0.38[0.54] \\
0.12[0.23]\end{array}$ & $\begin{array}{l}0.78 \\
0.29[0.54] \\
0.10[0.23]\end{array}$ \\
\hline
\end{tabular}

Notes: 1. Variables have been defined in the text.

2. Figures reported below each coefficient estimate are its standard errors.

3. * refers to significant at the 1 per cent level.

4. ${ }^{\star *}$ refer to significant at the 5 per cent level.

5. Figures in square brackets are critical values.

The results of the SYPC1 equation clearly shows that there is divergence in the growth of real gross state domestic product across states, which reconfirm the finding in the earlier section of this paper using the methodology of weighted coefficient of variation. The principal force driving convergence in the neoclassical growth model is diminishing returns to reproducible capital. Thus, states with lower initial values of capital-labour ratios will have high marginal products of capital and, therefore, will tend to grow at higher rates. However, as Hayami (2001) has argued, inefficient and poor-quality institutions and organizations could lead to violation of the critical assumption of diminishing returns to reproducible capital. This means divergence of income for a considerable period of time in the development process. Thus, it is logical to argue that the convergence hypothesis will hold only when country-specific institutions and organizations do not intervene in the process negatively to delay or constrain the convergence process. The distinction between growth that translates into 'a rising tide lifts all the boats' and growth that disproportionately favours some states, has been recognized by the Central government. In this context, it is worth citing the Indian Prime Minister's very recent statement, "The rapid growth achieved in the past 
several years demonstrates that we have learnt how to bring about growth, but we have yet to achieve comparable success in inclusiveness” (Planning Commission, 2008, p.iii). The implication here is that lack of effective functioning of proper institutions at the Central and state levels has been a problem, which may also be inferred from the following examples. The linkage between small businesses, medium-size enterprises and large- scale enterprises has not been strong. Integration from the production of raw materials up to the assembly of final products in the form of sub-contracting that one can see in the Japanese growth process discussed in Sonobe and Otsuka (2006) has been missing in the Indian growth process. In the context of agriculture, the dynamism that was generated by the Green Revolution had worked its way fully into production in the 1980s, and there was no alternative source of strong productivity growth (Kalirajan, Mythili, and Sankar, 2001). A lack of infrastructure and various policy constraints affecting agriculture productivity and trade have been major constraints on any technological breakthrough in agriculture, as discussed by Vaidyanathan (1995). Results of SYPC2, which show a smaller coefficient for agriculture relative to manufacturing, appear to support these inferences, particularly with respect to an urgent need for improvement in agricultural productivity.

As expected investment (INV) has positive effect on overall gross state domestic product growth and each percentage point change in investment with respect to AGRI_GSDP and MFG_GSDP leads to an increase in per capita growth by 0.038 and 0.056 percentage points respectively. It may be noted that there is a large variation in investment intensity across states and union territories; for example, for Pondicherry the intensity is 0.38, Gujarat 0.31, Rajasthan 0.20, MP 0.13, A \& N Islands 0.03, and for West Bengal 0.07. Clearly, if states such as MP were to raise its investment level to that of Gujarat, the per capita growth in agriculture and manufacturing would improve by 1.11 and 1.17 percentage points respectively. However, these effects are partial and conditional on other variables.

The second set of variables that are found to be important in growth process across states is the structure of the economy. For the 1993-2000 data sets, the structure of the economy during 1980-81 is considered as initial conditions in this paper. Several economists have advocated an agriculture-first strategy based on the confidence that agriculture has the capacity for technological dynamism (see Schultz, 1964 and 1978; Mellor, 1976; Adelman, 1984 and Oshima, 1993). According to Schultz (1978, p. 4), 'farmers the world over, in dealing with costs, revenues and risks, are calculating economic agents. Within their small individual allocative domain they are fine-tuning entrepreneurs, turning so subtly that many experts fail to see how efficient they are'. If this vision of farmers is correct, not only could agriculture supply wage goods and inputs but also, through technological modernisation, rising productivity, incomes and rural prosperity, the sector will stimulate growth in industry. For its part, industry can not only supply agriculture with modern production inputs, but also produce consumer goods to satisfy expanding consumer horizons. This perception of the 
intersectoral relation amounts to a dynamic two-way relationship between agriculture and industry. Support for this approach is drawn from recent experience in East Asia, particularly post-war Japan and Taiwan and the recent post-1978 reform experience in China. But does this 'growth multiplier effect' hold in the case of India? The results of this study are in contradiction to the 'growth multiplier effect'. The significant negative coefficient of initial manufacturing condition in the AGRI_GSDP equation implies that states with comparative disadvantage in manufacturing appear to grow faster in agriculture for their survival. Similarly, the negative coefficient of initial agricultural condition in the MFG_GSDP equation means that states with comparative disadvantage in agriculture appear to grow faster in manufacturing for survival. These results corroborate earlier findings by Ahluwalia (1985) and Shand and Kalirajan (1994).

Third sets of variables that are found to be significant in explaining variations in per capita overall growth and growth in agriculture and manufacturing are related to the social fabric of the Indian states. ${ }^{8}$ Drawing on Hayami (2001), they are in fact proxy to certain patterns of behavior of state governments, welfare organizations and culture of people in general. The variables falling in this category are initial condition of literacy rate across states, and share of population of scheduled tribes. Motivation for considering the latter variable and its expected effects is a bit complex and need some explanation.

The interesting result is that states with high initial levels of literacy rate appear to have higher per capita growth in gross state domestic product and also in per capita manufacturing growth, while such a relationship could not be established in the case of agricultural growth. The effect of share of ST population is positive and statistically significant on AGARI_GSDP, SYPC1, and SYPC2, while it is negative but statistically not significant in the case of MFG_GSDP. It is important to understand the genesis of these two different results. The people in tribal regions are mostly isolated from the cosmopolitan culture and bound tightly by local culture and traditional way of life (Table 3). Desire to change lacks in tribal regions and majority of them works as agricultural labourers in places nearby their habitations. It is true that states having larger ST population compared to other states enjoy more welfare programmes sponsored by both state and central governments. Such welfare programmes, which are mainly focused on rural areas, have spillover effects and likely to benefit all segments of the rural population. Thus, the welfare programmes provide a link between the presence of ST population and agricultural growth, though these programmes have not made significant impacts on the welfare conditions of the ST population. In this context, it is worth mentioning about the study by Kijima (2006), which argues that despite policies targeting scheduled tribes (ST), there remain large disparities of living standards between ST and non-ST households in India. A large part of the disparities between the ST

\footnotetext{
${ }^{8}$ It must be made clear that such variables, while explain differences in growth pattern across states, may not be construed to have causal relationship with growth.
} 
and the non-ST comes from the fact that the areas where the ST live are different from those where the non-ST live and that the education level of ST is remarkably low compared to nonST population.

\section{Table 3 Population shares and the growth pattern across States during 1993-94 to $1999-2000$}

\begin{tabular}{|c|c|c|}
\hline & Average growth (1993-07) & ST (1991 Census) \\
\hline$A \& N$ & 4.09 & 10 \\
\hline AP & 5.06 & 6 \\
\hline Arunanchal & 4.02 & 64 \\
\hline Assam & 2.65 & 13 \\
\hline Bihar & 4.44 & 8 \\
\hline Chandigarh & 10.28 & 0 \\
\hline Delhi & 9.33 & 0 \\
\hline Goa & 6.28 & 0 \\
\hline Gujarat & 7.03 & 15 \\
\hline Haryana & 5.64 & 0 \\
\hline $\mathrm{HP}$ & 6.81 & 4 \\
\hline $\mathrm{J} \& \mathrm{~K}$ & 5.07 & 0 \\
\hline Karnataka & 7.31 & 4 \\
\hline Kerala & 5.35 & 1 \\
\hline MP & 4.60 & 23 \\
\hline MH & 5.64 & 9 \\
\hline Manipur & 5.76 & 34 \\
\hline Meghalaya & 5.82 & 86 \\
\hline Mizoram & 3.13 & 95 \\
\hline Nagaland & 5.51 & 88 \\
\hline Orissa & 3.89 & 22 \\
\hline Pondicheri & 12.98 & 0 \\
\hline Punjab & 4.53 & 0 \\
\hline Rajasthan & 6.79 & 12 \\
\hline Sikkim & 7.73 & 22 \\
\hline Tamil Nadu & 6.88 & 1 \\
\hline Tripura & 7.00 & 31 \\
\hline UP & 5.33 & 0 \\
\hline WB & 7.07 & 6 \\
\hline All States & 5.87 & 8 \\
\hline
\end{tabular}

Quantitatively, each percentage point difference in ST population leads to increase in per capita agricultural growth by 0.03 percent. This result has significant implications for new states such as Chhattisgarh and Jharkhand where tribal population is dominant. There is a need to break this insulation of the region from the dynamism of the rest of the country. The average performance of this group needs to be changed. As Hyami (2001) has argued, it is imperative for the states to approach communities layer by layer to win their confidence 
and to educate them of the benefits of integrating with rest of the society, which is not found in tribal thinking (see for example, XaXa, 2001). The presence of ST population has no significant growth impact on manufacturing, which could be due to the poor literacy rate of the ST population.

\section{Measures of spatial disparity in development}

We present disparity patterns in other selected developmental indicators and then examine the patterns in states government expenditures that may be an important instrument influencing spatial development patterns across states.

We adopt the measure of weighted coefficient of variation to examine the trends in spatial balance in the basic development indicators: Infant mortality rate (IMR), Life expectancy at birth (LE), Literacy rate (LR), Telecom density per thousand population (TD), and per capita Electricity consumption (EC) in kwh, and the results are given in Tables 4 and 5. The trends clearly show that there is a reduction in disparity in literacy rate, and life expectancy at birth (see Table A1). In the case of infant mortality rate, the trends are less clear (Table 4). The trends in infrastructure development, which include telephone density and per capita electricity consumption, also show a general improvement, particularly in very recent times (see Table 5).

Table 4 The pace of development and spatial balance in development: Selected human development indicators

\begin{tabular}{|c|c|c|c|c|c|c|c|c|}
\hline \multirow[t]{2}{*}{ Year } & \multicolumn{2}{|c|}{ Life expectancy at birth } & \multirow[t]{2}{*}{ Year } & \multicolumn{2}{|c|}{$\begin{array}{l}\text { Infant mortality rate } \\
\text { (per thousand) }\end{array}$} & \multirow[t]{2}{*}{ Year } & \multicolumn{2}{|c|}{ Literacy rate } \\
\hline & Average & $\mathrm{CV}$ & & Average & $\mathrm{CV}$ & & Average & $\mathrm{CV}$ \\
\hline 1983 & 60.2 & 0.7398 & 1971 & 121 & 0.0565 & 1971 & 32.8 & 0.0830 \\
\hline 1988 & 61.1 & 0.7299 & 1976 & 123 & 0.0650 & 1981 & 42.2 & 0.0655 \\
\hline 1990 & 59.2 & 0.7541 & 1981 & 107 & 0.0681 & 1991 & 51.2 & 0.0575 \\
\hline 1991 & 59.7 & 0.7472 & 1986 & 95 & 0.0685 & 2001 & 63.9 & 0.0370 \\
\hline 1993 & 60.5 & 0.7376 & 1991 & 77 & 0.0708 & & & \\
\hline 1995 & 61.2 & 0.7298 & 1994 & 53 & 0.1237 & & & \\
\hline 1999 & 62.1 & 0.7197 & 1998 & 66 & 0.0670 & & & \\
\hline 2000 & 62.3 & 0.7175 & 2005 & 54 & 0.0680 & & & \\
\hline 2001 & 62.5 & 0.7157 & & & & & & \\
\hline 2003 & 63.0 & 0.7107 & & & & & & \\
\hline
\end{tabular}

Note: The coefficient of variation is calculated over data for 15 major states of India. The CV is estimated as a weighted measure using population shares of the states as weights. 
Table 5 The pace of development and spatial balance in development: Selected infrastructural development indicators

\begin{tabular}{|c|c|c|c|c|c|}
\hline \multirow[t]{2}{*}{ Year } & \multicolumn{2}{|c|}{ Telecom density (\% population) } & \multirow[t]{2}{*}{ Year } & \multicolumn{2}{|c|}{ Electricity consumption (kwh) } \\
\hline & Average & $\mathrm{CV}$ & & $\begin{array}{l}\text { Average } \\
\text { (per capita) }\end{array}$ & $\mathrm{CV}$ \\
\hline 1980 & 0.38 & 0.3350 & 1975 & 97 & 0.1157 \\
\hline 1985 & 0.40 & 0.1661 & 1980 & 121 & 0.1322 \\
\hline 1987 & 0.47 & 0.1717 & 1983 & 150 & 0.1335 \\
\hline 1988 & 0.48 & 0.1720 & 1985 & 168 & 0.1298 \\
\hline 1989 & 0.52 & 0.1726 & 1987 & 196 & 0.1352 \\
\hline 1990 & 0.55 & 0.1670 & 1990 & 232 & 0.1285 \\
\hline 1991 & 0.62 & 0.1654 & 1991 & 247 & 0.1244 \\
\hline 1992 & 0.71 & 0.1603 & 1992 & 263 & 0.1268 \\
\hline 1993 & 0.83 & 0.1592 & 1993 & 288 & 0.1197 \\
\hline 1994 & 1.00 & 0.1606 & 1994 & 306 & 0.1234 \\
\hline 1995 & 1.20 & 0.1629 & 1996 & 336 & 0.1235 \\
\hline 1998 & 1.68 & 0.1275 & 2002 & 359 & 0.1597 \\
\hline 1999 & 2.37 & 0.1499 & 2004 & 387 & 0.1523 \\
\hline 2000 & 2.68 & 0.1498 & & & \\
\hline 2003 & 4.24 & 0.1555 & & & \\
\hline 2004 & 5.69 & 0.1618 & & & \\
\hline 2006 & 10.74 & 0.1250 & & & \\
\hline 2007 & 15.85 & 0.1139 & & & \\
\hline
\end{tabular}

See Note to Table A1.

Thus, there has been an improvement in recent times in four out of the five development indicators considered, and the progress appears to be more spatially balanced than before. The movement towards more equitable levels of performance amidst rising development indicates that there are factors facilitating spatially equitable development. Nevertheless, the contribution of such factors towards achieving spatially equitable development is not uniform across states.

\section{Probable causes for differences in spatial patterns of development}

Given the divergence of state level performance seen in per capita GSDP and in few other basic developmental indicators such as infant mortality rate, it becomes necessary to distinguish between the need for spatially equitable development of so called basic services, which ensure that potential for development is evenly distributed, and the need for adequate incentives for creating favourable conditions for development by the states. 
The Central government intends to ensure equal access to basic services such as primary education, primary health care, infrastructure such as roads, drinking water, electricity and communication services across states. The norms for schools, primary health centres, roads and electricity infrastructure have been based on population and geographical units. However, the progress in this endeavour has been limited by availability of states' resources and the Central government usually takes various programs to assist the states. The recent initiative of the 'backward regions grant fund (BRGF)' provides support for the development of the less developed regions within India. Further, the new emphasis on 'inclusive growth' in the Eleventh Five Year Plan covering the period 2007 to 2012 is another reflection of diversity of growth experience across categories of population including regional categories (Planning Commission 2008).

Besides initial endowments and availability of resources, factors influencing spatially equitable development include innovations in institutional designs, which make scaling up of the development initiatives on a geographically wider scale (Kalirajan and Akita, 2002), and technological innovations (Otsuka, Ranis, and Saxonhouse, 1988). The mobile phones in telecommunications have made the task of bringing communication services to all geographical locations feasible now as compared to the situation that prevailed when the technology was limited to the land lines only.

How have the instruments of state and Central governments worked in achieving spatial equitable distribution in development in the Indian context? We examine this dimension of the process in the rest of this paper.

\section{Disparities in state government expenditures}

The state governments or governments at the provincial level account for bulk of the expenditures on social services in the country. They also provide funds for a variety of infrastructure services. Although a large part of these funds are devolved to the states through grants and loans by the central government, the expenditure takes place through state government machinery for providing services (Rao, Shand, and Kalirajan, 1999). The devolution and transfer of resources from the centre were budgeted at 16.7 per cent of the total disbursements of the state governments in 2008-09 (RBI, 2008). It is expected that the expenditures by states is based on norms that prove to be spatially equitable as the devolution of funds from the centre to the states is also guided to some extent by such principles. In this paper we do not elaborate on these principles, but only point to the two important mechanisms that govern the transfers, the Planning Commission, which determines the allocation of central government support to investment expenditures, and the Finance Commission, which determines the allocation of central funds to the states in the form of grants. 
While the devolution is partially governed by the equity principle, the state's own resources clearly hold the key for their expenditure levels. In other words, the devolution will have to do more than merely be equitable in order to reduce imbalances in development efforts. Does this happen? What has been the pattern of expenditures across states since the beginning of a policy regime which has been more reliant on markets to deliver growth than in the past? We examine the pattern of disparities in state government expenditures for five sub-periods: two for pre-reform years $1980-81$ to $1985-86,1985-86$ to $1990-91$ and three for post-reform years $1990-91$ to $1995-96$ and $1995-96$ to $1999-00$ and $1999-00$ to 2006-07 ${ }^{9}$. We have used revenue (or broadly, current expenditures) of the state governments for analysis as they make up about 77 per cent of total expenditures today. Within revenue expenditures, 'development expenditures' make up to 80 per cent of the spending. The development expenditures refer to expenditures on various socio-economic development programs in the social sectors and economic sectors.

The 'development expenditures' of the state governments within the 'revenue expenditures' are grouped into two broad categories: social services and economic services. The social services include health and education. The economic services include development programs in different sectors of the economy particularly in infrastructure. For example, revenue expenditures on programs relating to agriculture, roads, electricity, and industries are grouped under economic services. These are not capital expenditures but relate to expenditures on operation and maintenance of on-going programs.

Data are obtained from the Handbook of Statistics on State Government Finances (RBI, 2004) and previous publications on State Finances by the Reserve Bank of India (RBI). The state level population estimates are obtained by interpolating decadal Census estimates to obtain per capita expenditures for the states. The values in current prices are deflated by the wholesale price index to obtain expenditures and GSDP in real or constant prices. The results are summarised in Table 6 and illustrated in Figures 2 and 3.

The analysis shows that there has been an increase in the inter-state disparity in state government expenditures over the years, particularly if we compare the 10-year period before the 1990s and the period after the 1990s. Nevertheless, at the aggregate level, there also appears to be a cyclical pattern where the disparity begins to rise and then it begins to somewhat decline. The state expenditures, therefore, appear to have some in-built mechanisms that do not allow the disparities to rise continuously. However, development expenditure, particularly social services expenditure has been showing a declining trend in disparity across states gradually and consistently in recent times.

\footnotetext{
${ }^{9}$ The timing of beginning of economic reforms in India is somewhat controversial as some of the liberalization of policies, giving more room to markets in resource allocation had begun to take place in the 1980s (Panagariya, 2004). Basu and Martens (2007) provide a more detailed analysis of policies underlying the India's growth performance of the 1980s and 1990s.
} 
Table 6 Trends in disparity in state government expenditures: Coefficient of variation in per capita real expenditures (revenue expenditures)

\begin{tabular}{|l|c|c|c|c|c|c|}
\hline & \multicolumn{3}{|c|}{ Total Revenue Expenditure } & \multicolumn{3}{c|}{ Development Expenditure } \\
\hline Year & Development & $\begin{array}{c}\text { Non- } \\
\text { development }\end{array}$ & Total & $\begin{array}{c}\text { Economic } \\
\text { services }\end{array}$ & Social services & Development \\
\hline $1980-81$ & 0.0667 & 0.0755 & 0.0659 & 0.1005 & 0.0588 & 0.0667 \\
\hline $1985-86$ & 0.0713 & 0.0863 & 0.0735 & 0.0910 & 0.0729 & 0.0713 \\
\hline $1990-91$ & 0.0609 & 0.0525 & 0.0556 & 0.0796 & 0.0568 & 0.0609 \\
\hline $1995-96$ & 0.0950 & 0.0951 & 0.0767 & 0.1157 & 0.0859 & 0.0950 \\
\hline $1999-00$ & 0.0830 & 0.0850 & 0.0760 & 0.1169 & 0.0764 & 0.0830 \\
\hline $2006-07$ & 0.0806 & 0.0849 & 0.0759 & 0.1240 & 0.0752 & 0.0806 \\
\hline
\end{tabular}

Note: The figures in the table are coefficients of variation (CV) and they are weighted CV using state population as weights (Kalirajan and Akita, 2004).

We also provide another view of the pattern of inter-state differences in total state government revenue expenditures in Figures 4 to 6 as a supplementary exploratory analysis. The analysis suggests that the first sub-period before the economic reforms of the 1990s shows no significant pattern towards any change in the level of disparity. However, in the second sub-period of 1985-86 to 1990-91, there is more consistent pattern of decline in disparity. In the period since 1990-91, the disparity tended to increase first and then decrease subsequently.

Figure 2 Trends in regional disparity in government spending: coefficient of variation of real per capita state government expenditures

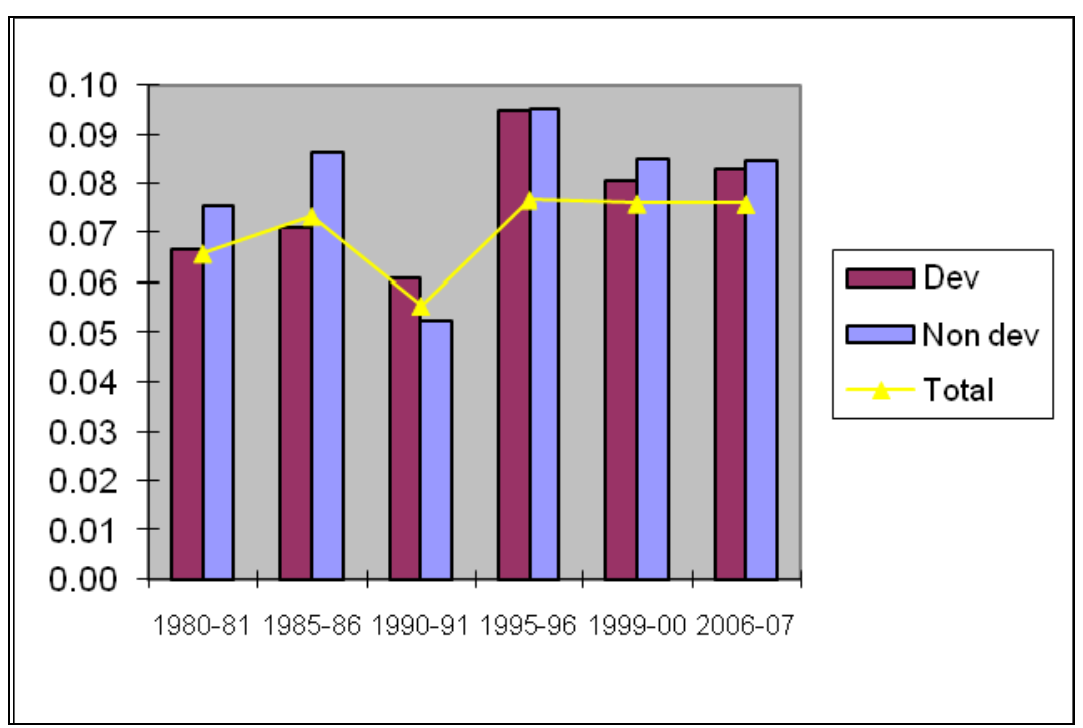


Figure 3 Trends in regional disparity in government spending: coefficient of variation of real per capita tate government revenue expenditures on development services

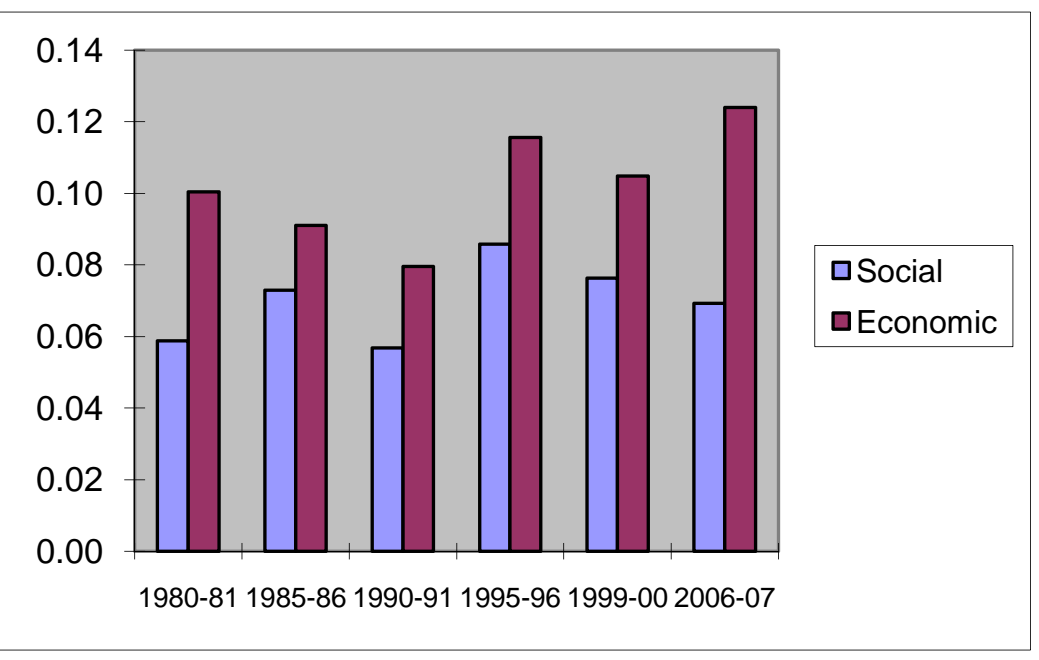

There are, thus, two patterns that emerge: an uncertain trend in disparity of per capita government expenditures during the period 1980-81 to 1985-86 followed by a declining level of disparity in the period 1985-90. Then we have the exactly opposite pattern in the period $1990-91$ to $1995-96$ and $1995-96$ to $1999-00$ and $1999-00$ to $2006-07$. However, it is important to examine how significant are these changes. The trends in government expenditures are, therefore, further examined in a regression model in the framework of the 'convergence analysis'. Although the underlying theoretical arguments are quite different, the methodology of income convergence analysis of Barro and Sala-i-Martin (1995) provides a useful tool to examine whether the disparity across states in state government expenditures is increasing.

Figure 4 Is there a catch up by the states with lower per capita expenditures: initial level of per capita revenue expenditure (X axis) vs. growth rate of expenditures ( $\mathrm{Y}$ axis)

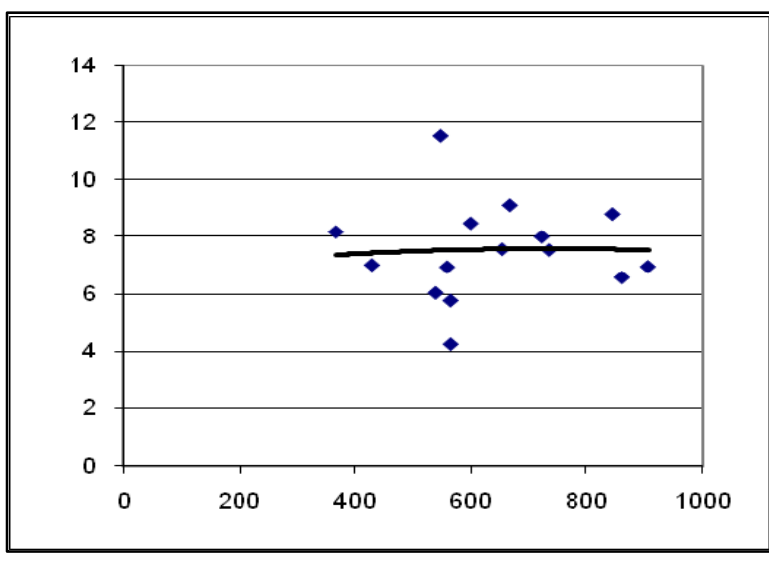

1980-85

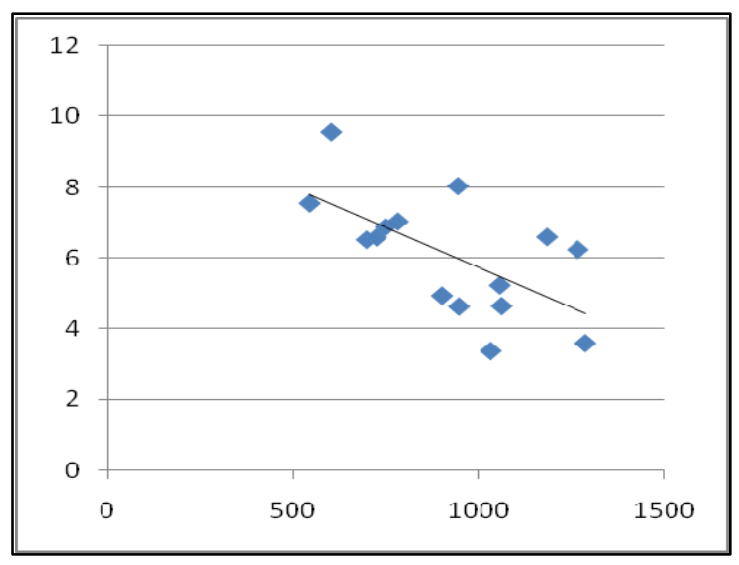

1985-90 
Figure 5 Is there a catch up by the states with lower per capita expenditures: initial level of per capita revenue expenditure ( $X$ axis) vs. growth rate of expenditures ( $Y$ axis) in the subsequent five years, 1990-81 to 1999-2000.

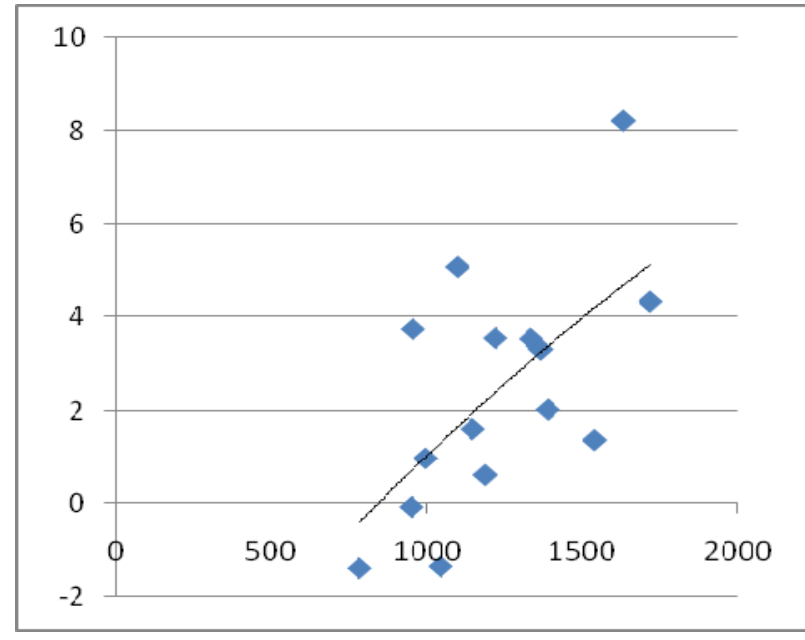

1990-91 to $1995-96$

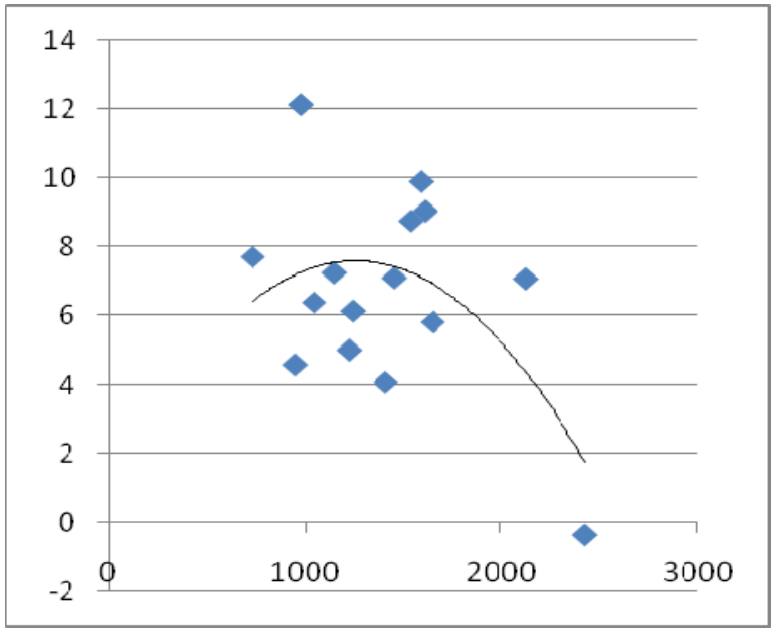

1995-96 to 1999-00

Figure 6 Is there a catch up by the states with lower per capita expenditures: initial level of per capita revenue expenditure (X axis) vs. growth rate of expenditures ( $Y$ axis) in the subsequent five years, 1999-00 to 2006-07.

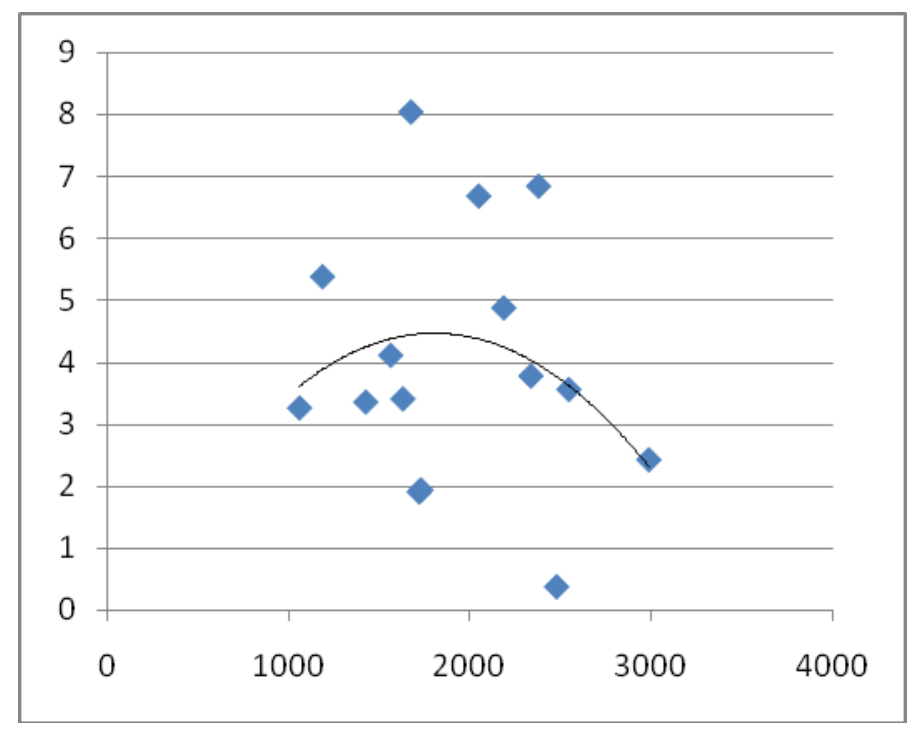

The basic regression model we used is:

$$
\begin{aligned}
& \left\{1 /\left(\mathrm{t}_{\mathrm{t}}\right)\right\} * \log \left(\mathrm{PCRE}_{\mathrm{t}} / \mathrm{PCRE}_{\mathrm{t}}\right)= \\
& \mathrm{a} 0+\mathrm{a} 1 *\left\{1 /\left(\mathrm{t}-\mathrm{t}_{0}\right)\right\} * \log \left(\mathrm{PCRE}_{\mathrm{t} 0}\right)+\mathrm{a} 2 * \log \left(\mathrm{PCY}_{\mathrm{t} 0}\right)
\end{aligned}
$$

Where

PCRE = Per capita real state government expenditures. 
PCY = Per capita real gross state domestic product (average of three years ending in year t or t0 in all cases except for 1980-81 where the average is for three years beginning in 1980-81; the averages are taken to remove abnormal data points).

$\mathrm{t}_{0}=$ Beginning year of the time period.

$\mathrm{t}=$ Ending year of the time period.

We have extended the analysis to cover seven types of revenue expenditures of the state governments: (1) total (2) development within total (3) non-development within total (4) expenditure on economic services within development expenditures (5) expenditure on social services within development expenditures (6) expenditure on medical and public health services within social expenditures and (7) expenditure on education services within expenditures on social services.

We have examined the pattern of expenditure for five periods:

$\underline{\text { Pre-reform periods }}$

1980-81 to $1985-86$

1985-86 to $1990-91$

$\underline{\text { Post-reform periods }}$

1990-91 to 1995-96

1995-96 to 1999-00

1999-00 to 2006-07

The detailed disaggregation of the expenditures and time period allows us to examine the sources of overall patterns. We are not particularly interested in the steady state levels of expenditures, but merely to examine if the expenditures across states are likely to be 'converging' or 'diverging' over time. The convergence would imply that the disparity is likely to be declining and divergence would imply the opposite. In the above equation, if the coefficient ' $a 1$ ' is positive, the per capita expenditures of the different states would be moving at different rates, with the 'higher expenditure state' increasing expenditures faster than the 'lower expenditure states'. Therefore, there would be no convergence of per capita expenditures across states and the disparity would increase over time. If the coefficient is negative, then the per capita expenditures would be converging or disparity would decrease over time. If the coefficient is zero, then again disparity would not be rising. The role of per capita real GSDP in the equation is to control for some 'initial conditions' of the state economy. If the average income (per capita GSDP) is larger in one state as compared to the other, the expenditures may also be higher because of the availability of larger resources (through own taxes) to that state. Once we control for this variable, the pattern that remains should reflect the influence of the other factors, including the devolution of resources from the Central government to the states, on the tendencies of the states to spend. 
The results obtained from applying the ordinary least squares method of estimation to equation (1) with different dependent variables with concerned independent variables explained above are summarised in Table $7 .^{10}$

Table 7 Summary of the results of regression analysis of inter-state disparity in state government expenditures:

\begin{tabular}{|l|c|c|c|c|c|}
\hline \multicolumn{1}{|c|}{ Expenditure type } & $\begin{array}{c}1980-85 \\
\text { (Pre-reform) }\end{array}$ & $\begin{array}{c}1985-90 \\
\text { (Pre-reform) }\end{array}$ & $\begin{array}{c}1990-95 \\
\text { (Post-reform) }\end{array}$ & $\begin{array}{c}1995-99 \\
\text { (Post-reform) }\end{array}$ & $\begin{array}{c}1999-06 \\
\text { (Post-reform) }\end{array}$ \\
\hline Total revenue & + & -0.1952 & 0.3505 & - & - \\
\hline Development & - & -0.1342 & + & -0.2193 & - \\
\hline Non-development & + & -0.3359 & 0.6023 & -0.2493 & - \\
\hline Economic Services & 0.3353 & - & + & - & - \\
\hline Social Services & + & -0.2696 & + & -0.2209 & -0.2987 \\
\hline Medical and public health & - & -0.4852 & + & - & -0.4048 \\
\hline Education & - & -0.2490 & + & - & -0.2848 \\
\hline
\end{tabular}

Note: The numbers in the table above are the estimated coefficients of initial level of per capita expenditure when significant at least at $10 \%$ level of probability; in all other cases, we have reported here only the signs of estimated coefficients.

Given our interest to find out whether there is convergence or divergence in per capita real state government expenditure and its components across states, we have only reported the signs of 'a1' and only some magnitudes of 'a1' that are significant, in Table 7 . The estimated coefficient 'a1' with respect to the total revenue expenditure is not statistically significant for the sub-period 1980-85, but turns significant and negative for the following sub-period 1985-90 implying convergence. In the early post-reform period of 1990-95, the coefficient is significant and positive implying divergence. However, in the later post-reform sub-periods, the coefficient is statistically not significantly different from zero implying that disparity did not increase.

The findings relating to total revenue expenditures are consistent with the previous assessment based on CV, if we consider the sub-periods that include 1990-91 as the terminal or initial year for some sub-periods. There is an apparent 'convergence' in the five-year period before the initiation of economic reforms and then a divergence in the immediate five years following the reforms of 1991. In the post-reform period, the pattern of divergence in the first sub-period of 1990-95 has also been pointed out by Rao, Shand, and Kalirajan (1999). The results show that for the total revenue expenditures, therefore, there has not been any consistent pattern of divergence or convergence. The macroeconomic crisis may have put greater pressure on 'higher expenditure' states to reduce expenditures leading to the

\footnotetext{
${ }^{10}$ Detailed results are not included here due to space restrictions. The results are with the authors and can be provided to interested readers upon request.
} 
'convergence' and the subsequent recovery may have led to restoration of expenditure pattern suggesting a 'divergence'.

While the overall per capita total revenue expenditure does not show consistent pattern of changes in disparity in the periods other than 1990-95 following the economic reforms, there are some consistent patterns in the sub-categories of expenditures. The so-called nondevelopment expenditures show statistically significant convergence for 1985-90, divergence for 1990-95 and convergence for 1995-99. The 'development expenditures' consistently show statistically significant convergence for $1985-90$ as well as for $1995-99$. Thus, the development expenditures appear to reflect a more consistent tendency towards lower disparity than the non-development expenditures. In other words, the 'development expenditure' is more pro-spatially equitable than the non-development expenditure.

When we decompose the development expenditures further, the differences within this broad expenditure category come to the fore. The expenditures on 'social services' show a statistically significant convergence pattern more consistently than the expenditures on economic services. In fact, the expenditures on 'economic services' show no convergence for any sub-periods considered, while the 'social expenditures' show convergence in three of the five sub-periods. Thus, state government expenditures on social sectors appear to be prospatially equitable than the expenditures on 'economic services'.

Within the 'social services', expenditures on both 'health' and education' services show statistically significant convergence for 1985-90 and 1990-96 indicating that the mechanisms driving these expenditures are based more uniformly on the needs of population across all regions of the country.

The analysis presented here has pointed to a number of characteristics of state government expenditures in the context of spatial equity of development. Though there was divergence in overall revenue expenditure across states in the early period of economic reforms (1990-95), in recent times there is also a mechanism that keeps the difference from growing further. The role of the state in this sense remains one of an attempt at reducing spatial disparity. The components of expenditures which provide this pro-spatial equity dimension to the state government expenditures are the expenditures on social services rather than the economic services.

The analysis presented here does not clarify, if the patterns of divergence or convergence are a result of higher growth of expenditures by the low expenditure states or declining rates of growth of expenditures in the 'high' expenditure states. In other words, the fiscal imbalances that result from increased expenditures may also act as a moderator of spending behaviour at the state level. The initial condition of average per capita GSDP does not influence the dynamics of expenditures. 


\section{Conclusions}

Balanced regional economic development has been a policy concern in India's development planning. In this paper, we provide an exploratory analysis of the patterns of disparity in development performance across the states and analyse the patterns in state level government expenditures to understand how they are aligned with the objectives of balanced spatial development within the national economy. We set out to assess the patterns of state level disparities in development using some broad basic indicators of development. Though the specific objective of keeping the disparities in development indicators from widening has been achieved with respect to some development indicators, there has been a growing concern that the less developed states continue to lag behind the developed states and that this cleavage is increasing. The policy concern is explicit in the latest eleventh five year plan (2007-08 to 2011-12), where inclusive growth has been a watch word. In this context, the paper refers to the sources of disparity and the role that may be played by the three pillars of development, the state, market, and community, articulated by Hayami (2004). The economic reforms of the 1990s have given more space to the markets in the allocation of resources as compared to the state relative to the pre-reform days. What implication does this have to the spatial equity in development? The state continues to be responsible for the supply of public goods including basic human capital and infrastructural development services across the country. Analyses presented in this paper suggest that the mechanisms by which state governments provide for resources for such services do not continuously lead to higher interstate disparity. If this pattern is a result of equitable sharing of central resources by the states, this element of state behaviour is important in keeping the inter-state disparities from widening. Further, the results also point out that the expenditures on basic services such as health and education are pro-spatially equitable than the economic services.

Overall, the results in this paper indicate that Government in India within a federal framework has mechanisms that foster development equitably across its states, particularly through health and education expenditures aimed at improving human capital development. However, the slowly rising disparities in economic services across states warrant the Central and state governments' attention. Drawing on Hayami (2001), it is conjectured that such tendencies arise mainly due to lack of appropriate and efficient institutions at the state and Central governments levels in India, which indicates the need for further institutional reforms. In this context, it is worth noting the following statement that appears in the Planning Commission's Eleventh Five Year Plan: “Much higher levels of human development can be achieved even with the given structure of the economy, if only the delivery system is improved” (Planning Commission, 2008, p.2). 


\section{References}

Abromovitz, M. (1986) “Catching up, Forging Ahead and Falling Behind,” Journal of Economic History, 46 (2), 385-406.

Adelman, I. (ed.) (1984) National and International Policies (London: Macmillan).

Ahluwalia, I. J. (1985) Industrial Growth in India, Stagnation since the Mid-sixties (Delhi: Oxford University Press).

Aoki, M., and Hayami, Y. (eds.) (2001) Communities and Markets in Economic Development (Oxford: Oxford University Press).

Barro, R. J. (1991) "Economic Growth in a Cross Section of Countries," Quarterly Journal of Economics, 106, 407-33.

Barro, R. J., and Sala-i-Martin, X. (1995) Economic Growth (New York: McGraw-Hill).

Basu, K., and Maertens, A. (2007) "The Pattern and Causes of Economic Growth in India," Oxford Review of Economic Policy, 23 (2), 143-67.

Bhattacharya, B. B., and Sakthivel, S. (2006) "Regional Growth and Disparity in India, Comparison of pre- and Post Reform Decades,” Economic and Political Weekly, 39 (10), 1071-77.

Bhalla, G. S. (1995) “Globalisation and Agricultural Policy in India,” Indian Journal of Agricultural Economics, 50, 8-26.

Fujita, M., Krugman, P., and Venables, A. (1999) The Spatial Economy: Cities, Regions and International Trade (Cambridge: MIT Press).

Gaile, G. L. (1980) “The spread-backwash concept,” Regional Studies, 14, 15-25.

Government of India (various years) National Accounts Statistics (New Delhi: Central Statistical Organization).

Hayami, Y. (1998, 2001) Development Economics (Oxford: Oxford University Press).

Hayami, Y. (2004) “The Community, the Market, and the State in Economic Development,” Paper presented at the Beijing Forum.

Hayami, Y. (2009) "Social Capital, Human Capital and the Community Mechanism: Toward a Conceptual Framework for Economists,” Journal of Development Studies, 45 (1), 96-123.

Higgins, B. (1983) "From growth poles to systems of interactions in space," Growth and Change, 14 (4), 3-13.

Hirschman, A. (1958) The Strategy of Economic Development (New Haven: Yale University Press).

Kalirajan, K. P., and Akita, T. (2002) "Institutions and Interregional Inequalities in India: Finding a Link Using Hayami’s Thesis and Convergence Hypothesis,” Indian Economic Journal, 50 (2), 47-59.

Kalirajan, K. P., Mythili, G., and Sankar, U. (2001) Accelerating Growth Through Globalization of Indian Agriculture (New Delhi: Macmillan).

Kelkar, V. L. (2004) “India: On the Growth Turnpike,” K.R. narayanan Lecture, Australia South Asia Research Centre, The Australian National University, Canberra. Accessed on 6 January 2009 at: http://rspas.anu.edu.au/asarc/narayanan_speaker.php?searchterm=2004.

Kijima, Y. (2006) “Caste and Tribe Inequality: Evidence from India, 1983-1999,” Economic Development and Cultural Change, 54 (2), 369-404.

Krugman, P. (2000) "Where in the World is the 'New Economic Geography? ” in G. L. Clark, M. P. Feldman, and M. S. Gertler (eds.), The Oxford Handbook of Economic Geography (Oxford University Press, Oxford: Oxford University Press). 
Mellor, J. W. (1976) The New Economics of Growth (Ithaca: Cornell University Press).

Oshima, H. T. (1993) Strategic Processes in Monsoon Asia's Economic Development (Baltimore: Johns Hopkins University Press).

Otsuka, K., Ranis, G. and Saxonhouse, G. (1988) Comparative Technology Choice in Development: The Indian and Japanese Cotton Textile Industries (Basingstoke: Macmillan).

Panagariya, A. (2004) "Growth and reforms during 1980s and 1990s," Economic and Political Weekly, 39 (25), 2581-94.

Parente, S. L., and Prescott , E. C. (2000) Barriers to Riches (Cambridge and London: MIT Press).

Porter, M. E. (2001) "Regions and the New Economics of Competition," in A. J. Scott (ed.), Global City Regions: Trends, Theory, Policy (Oxford: Oxford University Press), 139-57.

Planning Commission (2008) Eleventh Five Year Plan 2007-2012, Volume 1-Inclusive Growth (New Delhi: Oxford University Press).

Rao, M. G., Shand, R. T., and Kalirajan, K. P. (1999) "Convergence of Incomes across Indian States: A Divergent View,” Economic and Political Weekly, XXXIV(13), 769-78.

Reserve Bank of India (2004 and selected previous issues) State Government Finances, (RBI: Mumbai).

Reserve Bank of India (2008) Handbook of State Government Finances (RBI: Mumbai).

Rodrik, D., and Subramanian, A. (2004) "Why India Can Grow at 7 Per Cent a Year or More, Projections and Reflections,” Economic and Political Weekly, 39 (16), 1591-96.

Schmitz, H. (2000) "Does Local Co-operation Matter? Evidence from Industrial clusters in South Asia and Latin America," Oxford Development Studies, 28 (3), 323-36.

Schultz, T. W. (1964) Transforming Traditional Agriculture (New Haven: Yale University Press).

Schultz, T. W. (1978) Distortions of Agricultural Incentives (Bloomington: Indiana University Press).

Shand R. T., and Kalirajan, K. P. (1994) "India's Economic Reforms: Towards a New Paradigm?" Economics Division Working Papers, South Asia No. 1, Research School of Pacific and Asian Studies, Australian National University, Canberra

Sonobe, T., Hu, D., and Otsuka, K. (2002) "Dynamic Process of Cluster Formation and the Role of Traders: A Case Study of a Garment Town in China,” Journal of Development Studies, 39 (1), 118-39.

Sonobe, T., and Otsuka, K. (2006) Cluster-Based Industrial Development: An East Asian Model (New York: Palgrave Macmillan).

UNRISD (1968) Research Notes - A Review of Recent and Current Studies Conducted at the Institute, No.1, Geneva: United Nations Research Institute for Social Development.

Vaidyanathan, A. (1995) The Indian Economy: Crisis, Response, and Prospects (New Delhi: Orient Longman).

World Bank (2009) World Development Report 2009: Reshaping Economic Geography (The World Bank Group).

XaXa, V. (2001) "Protective Discrimination: Why scheduled Tribes Lag Behind Scheduled Castes," Economic and Political weekly July 21, 2765-72. 